\title{
Г.Н. КУЗЬМЕНКО
}

\section{ОТ ЛИТЕРАТУРНОЙ СКАЗКИ К ИСТОРИИ ЧЕЛОВЕЧЕСТВА: В ПОИСКАХ УТРАЧЕННОЙ РЕАЛЬНОСТИ}

Осуществлен анализ произведения А.С. Пушкина «Сказка о царе Салтане ...» средствами научной фольклористики. С опорой на труды исследователей народного творчества В.Я. Проппа, Е.М. Мелетинского и ряда других показана связь данной авторской сказки через народное творчество с исторической реальностью - с жизнедеятельностью родовой общины времен неолита. В качестве научной гипотезы предложено увидеть за сюжетом и персонажами «Сказки о царе Салтане ...» проведение свадебного ритуала членами двух экзогамных родов.

Ключевые слова: народное творчество, фольклор, волшебная сказка, авторская сказка, творчество А.С. Пушкина, фольклористика, история, неолит, родовая община, экзогамия, свадебный ритуал.

T ворчество автора разворачивается в социокультурном пространстве, фундамент которого история. Творчество автора литературной сказки может стать наглядным примером данного тезиса, так как используемый им фольклорный материал представляет сохраненный в преобразованном виде опыт поколений. В фольклористике существует устойчивая традиция исследования такого рода ретроспективной связи (А.Н. Веселовский, В.Я. Пропп, М.М. Бахтин, Ю.М. Лотман, Е.М. Мелетинский и др.). К сожалению, работы ученых редко выходят за рамки специализированного научного сообщества и остаются малоизвестными даже для студентов профильных направлений подготовки (лингвистика, антропология, этнография и т. п.). Какой уникальный аналитический ресурс остается при этом неиспользованным в учебно-методической и научной работе может продемонстрировать несложная герменевтическая операция с произведением, хранящимся в памяти с детских лет. В данном случае речь пойдет о произведении А.С. Пушкина «Сказка о царе Салтане, о сыне его славном и могучем богатыре князе Гвидоне Салтановиче и о прекрасной царевне-Лебеди».

Сюжет этой сказки хорошо известен любому образованному человеку, поскольку она входит в школьную программу по русской литературе. Напомним его вкратце. Царь Салтан женится на молодой девушке и забирает ее вместе с сестрами во дворец. В отсутствие царя его супруга родными сестрами оклеветана. Вместе с недавно рожденным сыном она заточается в бочку, бочка бросается в «бездну вод». Далее происходит их чудесное спасение, обнаруживается остров, на нем - волшебный город. Чудесно выросший сын царя - князь Гвидон становится правителем этого города. В это самое время во дворце злые сестры всеми способами стараются не допустить царя Салтана к семье. Князь Гвидон перелетает море в виде разных насекомых и подслушивает диалоги между своими тетками и царем Салтаном. Так он постепенно узнает об удивительных персонажах, обитающих в городе, в котором живут поющая белка под елью, молодые богатыри и дядька Черномор, прекрасная дева, которая обнаруживается в лице царевны Лебеди, помогающей молодому человеку со времени его появления на острове. Играется свадьба князя Гвидона и царевны-Лебеди, разделенная семья царя Салтана воссоединяется, злые сестры посрамлены.

Сказочный сюжет разворачивается молодым поэтом достаточно профессионально. Он в полной мере раскрывает свой талант в формах стиха, и в то же время, что касается содержания сказки, деликатно минимизирует свое авторство. За яркой фигурой поэта отчетливо видна глубокая тень его няни Арины Родионовны, растворяющаяся в безудержной стихии народного творчества. Связь произведения А.С. Пушкина с русским фольклором очевидна. С подлинной же исторической реальностью - нет. Эту связь выявляет фольклористика, одним из направлений которой стало исследование исторических корней народного творчества. Методологический арсенал этой науки позволяет показать за сказочными ситуациями и героями объективные ситуации и типажи далекого прошлого. В данном случае это обстоятельство позволяет увидеть не всегда лежащую на поверхности связь между авторским произведением, народным творчеством и исторической реальностью.

Начнем с загадки, за которой на самом деле серьезная исследовательская проблема. Почему злые сестры не отпускают царя Салтана в некий волшебный город? Напомним, что приезжающие купцы настоятельно рекомендуют царю посетить этот город, и царь не прочь этим рекомендациям последовать. Однако «ткачиха, повариха, сватья баба Бабариха» посетить остров царю не дают. Почему? В сказке нет ответа на этот вопрос. Может показаться, что злые сестры боятся встречи разлученных супругов. Но это не так такой боязни в произведении нет ни слова. Напротив, дело подается таким образом, что злые сестры (как и все другие участники злодейства) не знают о чудесном спасении оклеветанных ими царских жены и ребенка. Царь же после случившегося рассеян, печален, одинок. Нужно, казалось 
бы, поощрять его интерес к путешествиям. Чтобы развеялся он или заново женился. Ведь всплывает же в разговоре с купцами, «объездившими весь свет», ценная информация о прекрасной царевне Лебеди. Казалось бы, идеальный вариант для вдовца. Но нет, злые сестры противятся - «не хотят царя пустить, чудный остров навестить». Чтобы удержать царя, они раз за разом передают то ли в виде «молвы», то ли, может быть, в виде собственной выдумки какие-то нелепые чудеса. Белка, грызущая золотые орехи, в которых «ядра - чистый изумруд». Или - выходящие из морских глубин «в чешуе, как жар горя» тридцать три богатыря с командиром - дядькой Черномором. Наконец, демиургическая, подобная ночному небу дева, у которой «месяц под косой блестит, а во лбу звезда горит». Мотив удержания сестрами царя Салтана, особенно при помощи затейливых выдумок, абсолютно непонятен. Более того. Загадочным образом все озвученные сестрами чудеса обнаруживаются в том самом волшебном городе, в котором начал править спасшийся от неминуемой гибели сын царя - князь Гвидон. И чудеса не появляются из ничего, якобы назло коварным сестрам, как это могло бы показаться читателю. Нет, эти чудеса там существуют изначально, задолго до появления князя Гвидона: и дева, и ее братья - морские богатыри, и дядька Черномор, и белка-певунья с золотыми орехами. Правда, вначале князь Гвидон ничего из этого спектра чудес не видит. Он, собственно, даже волшебного города не видит. Князь Гвидон - только что прибывший заморский гость, поэтому и себя и свои тайны волшебный город открывает постепенно, как бы в ответ на возникающие у него вопросы.

Откуда же такие неожиданно точные описания чудес, которые исходят из уст злых сестер. Может, в связи с этим парадоксом стоит предположить, что злые сестры вовсе не фантазируют перед царем, не вспоминают какие-то небылицы, но обладают несомненным знанием о далеком волшебном городе? Однако это знание особенное, тайное. Поэтому проявить это знание сестры могут только в особой «намекающей» манере изложения, в виде как бы ни к чему не обязывающих фантазий или слухов. Предположение о том, что злые сестры знают о волшебном городе и о происходящих в нем событиях есть первый шаг к скрывающейся за фольклором исторической реальности. Ведь если мы допустим, что сестры (точнее, определяющие их поведение исторические прототипы) знают какие-то тайны иной части света, то естественным образом возникает вопрос - откуда они их знают? Чтобы ответить на него, мы должны будем выйти за рамки сказки, так как в самой сказке ответа нет. Есть невольная подсказка в самом начале произведения, противоречивом для вдумчивого исследователя. В хрестоматийном вступлении: «Три девицы под окном Пряли поздно вечерком $<. . .>$ И в светлицу входит царь, Стороны той государь <...> Здравствуй, красная девица, - Говорит он, - будь царица...». В приведенных строках для исследователя есть продуктивный диссонанс: А.С. Пушкин в данном случае не следует важному сказочному правилу, а именно царь и девицы, среди которых находится его будущая супруга, не могут быть из одного царства. Уже В.Я. Пропп отмечал, что в классической волшебной сказке брачные связи по своему характеру экзогамны. То есть, жених и невеста принадлежат разным народам (в исторической реальности - к родам). Исключающая инцестуозную связь экзогамия важна для архаичного общества, а жизнь этого, существовавшего многие тысячи лет назад общества, согласно В.Я. Проппу, наши сказки и отражают. Справедливости ради следует сказать, что мировая сказка не всегда эту экзогамию в браке показывает. Однако в других сказках Пушкина данное правило как раз очень строго соблюдено: Руслан и Людмила, Мертвая царевна и королевич Елисей, да и сами князь Гвидон и царевна Лебедь - это «дети разных народов».

Учитывая экзогамное правило брака, проявляемое в классических сказочных сюжетах, позволим предположить, что супруга и ее сестры привезены царем Салтаном в свое царство издалека. В таком случае, может быть, родина этих замечательных женщин и есть волшебный город, который расположен на острове в море? Отсюда закономерно их глубокое знание его тайн. Предложенный вариант определения родины сестер позволяет объяснить причину, по которой и сын царя также попадает в этот волшебный город и находит там себе жену. Перед нами интерпретированная сказкой брачная традиция между двумя экзогамными родами, повторяющаяся из поколения в поколение.

То обстоятельство, что в поисках своей невесты царь Салтан когда-то уже был в этом волшебном городе и стоя «позадь забора», подслушивал диалог девиц, ставит при прочтении сказки еще одну загадку. Ведь, царь Салтан, так или иначе, знает о городе и его жителях, в том числе, и о чудесных белке-певунье, морских богатырях и красавице деве. Ситуация, на первый взгляд, теперь приобретает явно абсурдный оттенок. Злые сестры знают о тайнах волшебного города. Царь Салтан знает об этих тайнах. Какой в таком случае смысл их препирательств перед купцами «объездившими весь свет»? К чему эти намеки, эти двусмысленные, не раскрывающие истинного местоположения рассказы о белке с орехами, о богатырях с дядькой Черномором, о деве с месяцем под косой и звездой? Смысл в озвучивании персонажами сказки этих диалогов есть, если помнить, что за ними стоят старшие родственники исторически реального жениха. На первый план здесь для нас вполне закономерно должен выйти главный персонаж сказки - князь Гвидон, который в виде насекомого, раз за разом, прилетает в тронный зал отца-царя. Он слышит эти диалоги, и они служат ему подсказками дальнейших действий. Видимо, князь Гвидон и есть истинный адресат разыгрываемой интермедии. Князя Гвидона - женят. В описанных А.С. Пушкиным мизансценах явлена реальная ситуация, когда в соответствии с экзогамным правилом молодого человека (исторического прототипа князя Гвидона) направляют в род матери для выбора невесты. В качестве сопровождающего сына царя Салтана в сказке - его мать. Мать Гвидона ведет себя в волшебном городе скромно и просто, незаметно. Но и в этом очередное проявление реальной истории - в городе эту женщину знают, выбирая ее сына сразу в князья. 
Не такая уж простая она «девица» и ее сестры, соответственно, тоже. По статусу они равны царю Салтану, так как простолюдинок цари в жены не берут даже в сказке (почему создается обратное впечатление, это уже отдельная история). А то, что они ткут по вечерам («пряли поздно вечерком»), так это нормальное для архаичного общества времяпровождение для женщин. Ткачество - это древнейшее магическое искусство, в фольклоре ткут богини, царевны и принцессы. Из героинь уже классических поэм, выросших из фольклорных сюжетов, можно вспомнить Пенелопу, ткущую ковер в ожидании царственного супруга.

Свою роль в развитии сюжета играет живущая на острове царевна Лебедь, за образом которой скрывается исторический персонаж невесты. При внимательном прочтении сказки видно, как она координирует свои действия со старшими родственниками своего будущего супруга. Именно благодаря ее манипуляциям князь Гвидон превращается в насекомое и улетает за купцами к царю Салтану, где узнает о разных чудесах. А чудеса, подчеркнем, одно за другим, осторожно подводят его к мысли о необходимости женитьбы. К тому же, скрывающаяся за образом царевны Лебеди невеста - из одного экзогамного рода с матерью своего жениха. Царевна, мы видим по тексту сказки, старается показать все свои достоинства. В исторической реальности эта презентация была важна не столько для будущего мужа, сколько для будущей свекрови. И в сказке рядом с царевной Лебедь ненавязчиво находится жена царя Салтана, мать ее жениха и - ее собственная тетя.

Если за жителями волшебного города скрывается исторически реальная родовая община, то для исторического прототипа царевны Лебедь это место есть ее малая родина, населенная родственниками. Родство морских богатырей признает сама царевна-Лебедь - «эти витязи морские мне ведь братья все родные». Безусловно, в этом случае является ее старшим родственником «дядька» Черномор, возглавляющий богатырей. Если за царем Салтаном и дядькой Черномором скрываются главы экзогамных родов, то, следовательно, они знакомы друг с другом и заранее (возможно, еще до рождения жениха и невесты) оговорили свадебный сценарий. В научной литературе это называется «свадебным сговором».

В историческом контексте родственником царевны Лебеди может быть и Коршун, который ее терзал в безжалостном поединке. Напомним, битва Коршуна и Лебеди - это первое, что увидел Гвидон при своем появлении на острове. Эта битва, скорее всего, искаженный поколениями сказочников обычный для древней родовой общины ритуал инициации девушки перед замужеством. Цель архаичной инициации, напомним, доведение «посвящаемой» старшими родственниками девушки-подростка до особого состояния, позволяющего войти в контакт с духами предков. Одновременно происходит проверка качеств пришедшего за ней жениха, именно поэтому Гвидон и становиться участником сказочного поединка. За Коршуном, по словам царевны, скрывается какой-то колдун. «Ты не коршуна убил, говорит она после удачного выстрела князя Гвидо- на, - чародея погубил». Не исключено, что Коршун - это тотемическая маска Черномора, так как глава рода и есть главный маг, проводящий обряд инициации. Такого рода раздвоение одного лица, иначе - обретение маской собственного бытия прослеживается и в женских персонажах сказок А.С. Пушкина. Так, в «Сказке о мертвой царевне и о семи богатырях» мачеха, оставаясь неизменно красивой, отправляет вредить главной героине некую старуху-Чернавку. В то же время в западноевропейской сказке «Белоснежка...» (Ш. Перро, братья Гримм), инвариантом которой является пушкинская «Сказка о мертвой царевне», красавица-мачеха оборачивается в старуху-вредителя сама. Возвращаясь к связи образов Черномора и Коршуна, отметим, что в еще одной сказке А.С. Пушкина - в «Руслане и Людмиле» под именем Черномора выведен злой колдун, умеющий летать; он похищает главную героиню подобно уже упомянутой хищной птице - «Носился, плавал коршун серый И пал как молния».

Если рассуждать о других близких родственниках невесты из волшебного города далее, то таковой окажется и белка, грызущая орешки под елью. Если Лебедь оказывается царевной, то и Белка, наверняка, так же девушка царского происхождения. Белка имеет отношение к золоту и драгоценным камням, Белка «поет при честном при всем народе», то есть она говорит человеческим языком. Иными словами - она маг, оборотень, что автоматически свидетельствует о ее высоком социальном статусе. Только, в отличие от старшей сестры, у нее нет жениха, что позволило бы ей сбросить звериную шкуру. Следует заметить, что статусные молодые люди, ожидающие своего звездного часа в шкуре животного, - излюбленная тема сказочного повествования («Принцесса - Ослиная шкура», «Царевна-лягушка», «Царевна-змея», «Финист ясный сокол», «Ганс-еж» и др.).

Если же сосредоточить внимание на главном герое - князе Гвидоне, то его исторический прототип также не объект, а субъект сказочного действия, витязь, фактически, решающий трудные задачи. Он так же активно, как и окружающие, демонстрирует свои недюжинные магические способности. Гвидон растет «не по дням, а по часам». 0н знает язык животных. Он повелевает стихиями, ибо бочку, в которой он путешествует с матерью, море прибивает к берегу по его слову — он сказал «... и послушалась волна». Он убивает колдуна. 0 н, переходя с одного магического уровня на другой, открывает чудесных персонажей волшебного города, невидимых для глаз обычного человека. 0н возглавляет волшебный город. А его удивительная способность превращения в разных насекомых (комара, муху, шмеля) означает, что князь Гвидон есть оборотень.

Наконец, совсем не случайна странная, на первый взгляд, суета при его рождении, которая выразилась в знаменитой фразе «Родила царица в ночь Не то сына, не то дочь; Не мышонка, не лягушку, А неведому зверюшку». Делают этот оговор матери-царицы, скажем более - этот изощренный намек на ее внебрачную связь - опять же пресловутые злые сестры. Если сестры, как и в случае с 
волшебным городом, владеют неким табуированным знанием, которое открыть нужно, но иносказательно, то они своими словами указывают на некую тайну в рождении князя Гвидона. Безусловно, такая тайна есть. Проблемное отцовство вообще благодатная почва для любого культурологического исследования. Проблемное отцовство есть результат иерогамии - священного брака матери героя с предком, тотемом, богом или иной потусторонней персоной. Это достаточно распространенное явление, корни которого, опять же, скрываются в архаичных условиях инициации девушки, которую осуществлял ее старший родственник в качестве посредника между мирами. Дефлорация невесты, как тогда представлялось, предками ее рода, которые входили в верховного мага во время ритуала, кроме всего прочего, ставила под сомнение родство первенца законному мужу. Отсюда древний обычай приносить первенцев в жертву, то есть возвращать его предкам обратно, хотя, конечно, жертву могли и отложить на потом. Оставшийся в живых результат иерогамии - это волшебный ребенок, вырастающий в мага. В спасителя, в учителя, в мудреца. Легенды и священные тексты, дошедшие до нашего времени, насыщены такими культурными героями. Получается, что пушкинский князь Гвидон из их числа. Из этого же обстоятельства, кстати, вырастает интересная проблема убийства главным героем чудовища, на которую обращают внимание, как правило, только специалисты, хотя она запечатлена даже в гербе Москвы. В жилах героя течет кровь чудовища, поэтому-то он и способен его победить. В данном случае, подстрелить Коршуна, терзающего прекрасную царевну Лебедь.

Стиль научно-популярного эссе, который принят в данном случае для исследования «Сказки о царе Салтане» имеет свои преимущества и недостатки. Конечно, интерпретация текста А.С. Пушкина в таком стиле недо- статочна, однако она позволяет заявить гипотезу: в этом произведении, пройдя через преломление во множестве фольклорных сред, отразился свадебный ритуал времен евроазиатской родовой общины (начало неолита и даже ранее). Влияние древнейшего свадебного ритуала на содержание волшебной сказки в свое время обозначил В.Я. Пропп в классическом труде «Исторические корни волшебной сказки». В частности, он артикулировал связь между испытанием жениха со стороны рода невесты и испытанием сказочного героя в сказке, утверждая, например, что в некоторых ипостасях Бабы-яги скрыта теща [1]. Еще подробнее этот вопрос разбирал Е.М. Мелетинский, резюмировав, что в поздней редакции сказки «вместо ухода в свое царство будет похищение царевны в чужое царство, героиня будет не дочерью, а пленницей-наложницей демона; испытание главного героя в ином царстве примет характер не решения задач тестя, а борьбы с противником» [2]. Автор настоящей статьи также издал монографию, развивающую эту тему [3].

Таким образом, пример отдельно взятой сказки А.С. Пушкина показывает, что связь между авторским произведением, народным творчеством и исторической реальностью гораздо глубже и сложнее, чем может казаться на первый взгляд.

\section{Список литературы}

1. Пропn В.Я. Исторические корни волшебной сказки // В.Я. Пропп: собр. тр. - М.: Лабиринт-МП, 1998. C. $146-202$.

2. Мелетинский Е.М. Женитьба в волшебной сказке (ее функция и место в сюжетной структуре). - М., 1998. - С. 306.

3. Кузьменко Г.Н. Василиса Премудрая. Сказочные проекции архаичного образования. - М.: Инфра-М, 2014.

\section{К.Г. КУДРЯВЦЕВА}

\section{НЕКОТОРЫЕ МИФОЛОГИЧЕСКИЕ МОТИВЫ В АПОКРИФАХ ВТОРОГО ХРАМА И ОТКРОВЕНИИ ИОАННА БОГОСЛОВА}

\footnotetext{
Рассматриваются две фольклорные темы: свечение и противостояние светлых и темных сил в погоне за светом. Текстами, составившими основу для исследования обозначенных явлений, стали работы, прежде всего, конца эпохи Второго Храма - апокрифы «Иосиф и Асенет», «Четвертая книга Ездры» и последняя книга Нового Завета, Откровение Иоанна Богослова. Особое внимание уделено анализу и интерпретации основных образов Откровения Иоанна Богослова.

Ключевые слова: мифология, Откровение Иоанна Богослова, апокрифы, погоня за солнцем, внутреннее и приобретенное свечение, женщина-город, числовая символика.
} 